\title{
Refiguring the Romantic Body: Chinese Women Pianists in the American Conservatory
}

\author{
Audrey Vardanega
}

Citation: Vardanega, Audrey. Refiguring the Romantic Body: Chinese Women Pianists in the American Conservatory. Columbia Undergraduate Research Journal, 2017; 2:2.

\section{Introduction}

When the twenty-four-year-old pianist Yuja Wang walked on the stage of the Hollywood Bowl in a tight, short orange dress on August 2, 2011 to play the Third Rachmaninoff Piano Concerto under the direction of conductor Lionel Bringuier, Wang's attire was interpreted as a transgression of normative expectations for classical performers. The Los Angeles Times reviewer Mark Swed described her dress as "so short and so tight that had there been any less of it, the Bowl might have been forced to restrict admission to any music lover under eighteen not accompanied by an adult...had her heels been any higher, walking, to say nothing of her sensitive pedaling, would have been unfeasible" (Swed 2011). The New Criterion reviewer Jay Nordlinger characterized it as "stripper-wear," raising the question of how perceptions would change if the "pianist sitting before us were not a [tasteless] brash girl...but an antique, venerable Austro-German Meister" (Nordlinger 2011). Both critics' comments highlight the significance of the body in classical music performances-where Wang's clothing style or "stripper-wear" heightens the visibility of her body and draws attention to her sexiness, problematizing critics' expectations for the comportment of the performing body (Ameer 2011).

These critics are not simply reacting to Wang's interpretation of Rachmaninoff's virtuosic concerto-rather, they are responding to the presentation of her body. Rather than viewing Wang as a "bad girl" pianist who seeks to "subvert the patriarchy" through bandage dresses, I interpret the critics' reactions to Wang's performance not as a response to the heightened visibility of her feminine figure, but as symptomatic of 
the centrality of the woman's body in the project of locating 'good' music performances. Although Nordlinger imagines replacing Wang's embodied presence (as a young Chinese woman) with that of a masterly Austro-German man, he does not wish to change or affect the music itself. His comment stems from the notion of a detachment between the bodies and selves of musicians and the music itself-a logic with ramifications for the bodies of women performers like Wang.

The concept behind Nordlinger's notion stems from German Romantic ideals, ideals that claim a performer bridges two discrete selves on stage: that is, an extramusical self and a performing self. The performing body serves as the site of interaction between these two selves, demanding the disappearance of the extramusical self in the pursuit of "pure" conveyances of western classical music. The extramusical self encompasses the subjects' political and social attachments in the world, attachments that should be excluded from a performance. Musicologist Suzanne Cusick explicates the role of the body in 'pure' performances with her notion of the "spectacle of the disappearing Self" (Cusick 1994, 84). Cusick conceives of the body not as a site for a dual self, but as the site of a strategic disappearance where the extramusical self disappears in the service of the composer's ideals. Describing a performance of Schumann's Lieder by singer Jessye Norman, Cusick describes her own "deep desire for Norman to disappear into the woman Schumann wanted to imagine" in order to derive a listener pleasure from "witnessing the spectacle of her faithful performance, which is the spectacle of the disappearing Self" (Ibid). This spectacle of disappearance extends from N.K. Griffiths' claim that soloists' bodies embody musical works and help direct focus to the work performed. In order "for the prominence of the work itself to be maintained, reference to the human origins of performance [have] to be disguised" (Griffiths 2011, 31). This Romantic paradigm idealizes the performer's presence by necessitating the disappearance of her extramusical self.

This duality has ramifications for women's bodies. The Romantic demand for selves to disappear and give in to the conveyance of pure music is countered by the concerns of feminist musicologists. This actaccording to Cusick-extends from and perpetuates patriarchal 
structures. The staged performance of pure music displays "the correct relationship of a subaltern to hegemonic power, the relationship of submission" (Cusick 1994, 92). The woman performer's act of bringing forth a good performance could be construed as a "real and metaphorical performance (or spectacle) of cultural hegemony," or a perpetuation of patriarchal constructs through the act of Romantic performance itself (Ibid 91). When the performer in question is a woman like Wang, this Romantic paradigm engenders the subalternity of the woman's body. In this context, the study of women classical performers becomes a feminist endeavor that necessitates a critical examination of the sophisticated ways that Chinese women pianists like Wang consciously refigure this dominant framework.

This article investigates how Chinese women pianists like Wang refigure Romantic expectations for staged performances instead of complying with its norms. Chinese women, I argue, invert Romantic expectations from within given their experiences in China and the United States. This is best understood through José Esteban Muñoz's notion of the disidentificatory subject who "tacitly and simultaneously works on, with, and against a cultural form within ideology" (Muñoz 1999, 12). Chinese women pianists are caught between two demands-on the one hand, the Romantic conception of the performer's role in producing pure music and on the other hand, a pull on their singularity due to their particularity as Chinese subjects in the United States. Chinese women make their extramusical particularity central to their performances within Romantic regulations. This refiguration significantly changes the relation between their performing bodies and the expectations for conveying music.

\section{Romantic Bodies}

Romantic music is founded on "transcending generic boundaries," whether these are the boundaries of the body, the world, or the work of music itself (Daverio 1993, 6). Romanticism calls for "the idealization of uniqueness and creativity, the possibility of synthesizing the most disparate entities, the omnipotence of the poetic imagination, the organic quality of life and art" (Ibid). The paradigm, which celebrates purity and 
individuality, thus raises questions regarding the role of the individual in relation to music, especially when music is thought to come down from a higher source. Purity in music is best understood in terms of E.T.A. Hoffmann's notion of absolute music, which marks music's transcendence and sublimity. Hoffmann states:

Instrumental music must avoid all senseless joking and triviality, especially where it is intended to be taken as absolute music and not to serve some definite dramatic purpose. It explores the depths of the soul for the presentiments of a joy which, nobler and more beautiful than anything experienced in this narrow world, comes to us from the unknown land; it inflames in our breasts an inner, rapturous life, a more intense expression than is possible through words, which are appropriate only to our limited earthly feelings. (Locke and Hoffmann 1917, 132)

It is clear that Hoffmann understands instrumental music as akin to a religion in which music delivers joy that is "nobler and more beautiful than anything experienced in this narrow world" that "comes to us from the unknown land." Although music is created and interpreted through the work of individual creativity, Hoffmann calls for an absolute music that is bestowed by a higher entity and transcends social or political functions. The Romantic musician straddles a contradictory dichotomy: she makes the decisions that achieve a pure interpretation of Romantic music but simultaneously must conceal the social and political traces related to herself. Although Hoffmann was writing in the 1800s, his notion of music as a quasi-religious vessel for the transcendent has become entrenched in western classical music performances. The musician's body becomes the site for delivering purity. When I refer to Romanticism or to Romantic beliefs in this article, I refer to this idealized and conditioned splitting of the individual in the pursuit of a transcendent yet organic conveyance of music.

This paper interrogates the lingering effects of Romantic traditions on Chinese women pianists' subjectivities in two political spaces, the Chinese living room and the American practice room. I focus on the lives of Chinese women studying in American music conservatories who, in traversing both territories, generate meanings through refiguring regulations on their relationships to the piano. Chinese women pianists 
are intimately familiar with two different traditions that bring to life the Romantic paradigm of the solitary artist in different ways: the familial relationship to the piano in the Chinese state and the institutionalized individual relationship to the piano in the American music conservatory. Chinese women tacitly disturb demands for the disappearance of their extramusical self by making their experiences as both Chinese and American subjects central to their performances.

I draw on Mari Yoshihara's Musicians from Another Shore, a book that describes how Asian classical musicians experience music in American music conservatories. Yoshihara critiques the dominant portrayals of Asian and Asian-American musicians as naturally suited (by virtue of their cultures) to the demands of classical music performances. Yoshihara elucidates the ways that Asian musicians make sense of their own racial identities by "[enabling] a conception of authenticity that is simultaneously faithful to the original music and to themselves" through personal appropriations of norms in western classical music (Yoshihara 2007, 192). She describes how Asian musicians ground their perceptions of good performances in notions of the detachment between their extramusical selves and classical music.

I extend Yoshihara's investigation by analyzing the state and institutional structures that shape the lives of Chinese women pianists. In my own interviews of Chinese women pianists in conservatories, I encountered responses that affirm Yoshihara's claims about the depoliticized nature of western classical music. Each of my respondents tells a story of their relationship to the piano, inseparable from their intimate experiences of two different Romantic traditions. I was fortunate enough to hear these stories from eleven Chinese women pianists who have attended American music conservatories, including the Juilliard School, Mannes College, New England Conservatory, and Oberlin. All of them are pursuing careers in music, whether as chamber musicians, soloists, or piano teachers and have deep experiences as performers of western classical music both in China and the United States. They range between twenty and thirty years old, and, for the most part, came to the United States in their late teens to pursue piano study at a prestigious American music school. 
By focusing my analysis on Chinese pianists situated in American music conservatories, I explore the effects of transnational power structures, showing how Chinese women pianists respond to regulatory structures by repurposing Western ideologies of Romantic authenticity through embodied means. Chinese women pianists use their bodies in significant ways to destabilize the regimes that necessitate the disappearance of the self. The body both troubles and rehabilitates Romantic paradigms, in that it is not simply a complicit means of perpetuating norms, but it also becomes a site of articulating a particularity that requires the appearance of the self. In other words, the body animates the disidentificatory component of Chinese women's subjectivities, emerging as a site of resistance through the rehabilitation of norms of good performances (Muñoz 1999, 12). Chinese women pianists, after facing regulations in the American conservatory and Chinese cultural contexts, not only articulate Romantic ideologies in terms of a relationship to the piano that carries the traces of the Chinese context. They also use bodied means to invert regulations into a creative force for their own lives.

The problems that arise from this hypothesis are twofold. First, how do Chinese women respond to two Romantic ideals that animate musical performances in China and the United States? Secondly, how do Chinese women pianists refigure Romantic regulations in their relationships to the piano? In interrogating these problems, I explore the significance of the piano in the Chinese context with its ramifications on family structures. The Chinese state mobilizes a particular Romantic relationship between families and the piano understood through Confucian ideals that also serves a social purpose of controlling reproduction. Then, I examine how this Chinese familial relationship with the piano is displaced by the curricular structure of the American music conservatory, generating feelings of loneliness among Chinese women. Although loneliness is not at all limited to the experiences of Chinese women pianists, I contend that they feel loneliness more saliently given the disciplinary structure of the conservatory and the cultural challenges of moving to the United States. The American conservatory uses practice regimes and its curricular structure to discipline Romantic individuals, conditioning a detachment between my respondents and the familial basis of their musical engagements. I chart 
the ways that such loneliness is accompanied by a deep emotional and personal attachment to music that does productive work. My respondents refigure Romantic expectations into a productive force for their own lives, speaking to the need for a new understanding of Romantic paradigms in order to accommodate the nuanced life techniques of Chinese women pianists.

\section{The Chinese Context: The Influence of the One-Child Policy}

In contemporary China, Romantic ideals are reinterpreted by means of Confucian ideals to become part of a means of social control in the Chinese state. In my respondents' statements, piano education had significant ramifications on their families. Yifan Yin's family was deeply involved in her piano education and struggled to accommodate the piano in their lives. Yin, a Chinese pianist studying at Mannes College in New York City, describes how her parents devoted their savings to her piano education:

My mom spent most of her savings to get me this big toy (a piano) and so that is the beginning of my piano learning... My family used to live in the northern part of China, but we moved to Beijing in order to get a better education of my studying on piano [sic]. My parents got separated since then, and they had a lot of fights as I remembered. (Yifan Yin, in conversation with the author, October 2016)

Yin describes how her family made significant changes in their home life to accommodate her life at the piano. Yuejiamin Ying, a pianist enrolled at Mannes College, similarly describes her family's sacrifices to accommodate her piano playing:

In my 5th grade year, I started working with a teacher of Shanghai Conservatory. My mother (sometimes my father) and I went to Shanghai once a week, it took five hours to get to Shanghai and five hours back. My parents have to work harder during weekday [sic] so that they can go with me. Plus, learning music really takes a huge amount of money in China. To be honest, learning music almost takes all of money of my family [sic]. (Yuejiamin Ying, in conversation with the author, October 2016) 
Ying's statement on how "learning music almost [took all the money of her family]" is one instance of the broader economic restructurings made by Chinese families for the sake of classical music education. Not only did the bulk of Ying's family's money go to her music education, but her parents also restructured their work lives by "working harder during weekdays" to accommodate a ten-hour journey to Shanghai over the weekend. Xueying Fan, a pianist currently studying at the New England Conservatory, affirms Ying's statement about the significant familial economic investments for piano education. Fan states:

To be honest, it made my family poorer. My mother quit her job to keep company with me in Shanghai (very far from my hometown) for my piano education. My father is the only economic supporter in my family. (Xueying Fan, in conversation with the author, October 2016)

Lidong Xu, a student at the Juilliard School, claims:

Because of my piano study, my mom quits [sic] her job in order to take care of me better and my father changed his job so the family can [sic] move to Beijing for music school" (Lidong Xu, in conversation with the author, January 2017).

Fan, Yin, Ying, and Xu describe a distinct experience of the piano that disturbs the logic of the musician as a vessel for sublime music, unaffected by her social or political life. The child's piano education in the Chinese context has significant ramifications on understandings of the family. Each of the women describes the significant ways that families struggled financially and emotionally; in some cases, their families broke up for the sake of piano education. In order to grapple with the ways that families struggled for the sake of the child's piano lessons, we must first interrogate the historical meanings of western classical music in China.

The piano's role in the Chinese project is twofold-it serves as a Confucian device for bringing up proper children as well as a means of regulating the Chinese population. In the 1960 s and 70 s, western classical music assumed a political function in mediating a transnational encounter between the United States and China. During the political shift from the Cultural Revolution to the Chinese détente with the west in 
1970, Chinese political subjects used western classical music as an integral mechanism of political negotiation. With the implementation of the one-child policy, Chinese families actively incorporated western music education in the lives of their children as a technique of raising children with good character, deviating from western Romantic paradigms for Confucian ideals.

\section{The Piano and the Woman's Body}

With the institution of the one-child policy in the 1980s, the piano emerged as a hidden means of cohesion for the new configuration of the nuclear family. The familial accommodations of the piano opened up new techniques of social regulation by the Chinese state. The Chinese postCultural Revolution shift towards modernity reconfigured families. This familial shift was a response to a combination of factors: the 1978 postRevolution economic reform that targeted the development of China's industrializing capabilities, the development of social welfare programs, the reduction of births in the population, and the 1980's one-child policy that targeted growing urban areas (Cao 2012,156). With the emergence of modern industries and the welfare state, the Chinese family shifted from "the dominant extended family of pre-modern society" to "the nuclear family" (Ibid). Chinese subjects responded to the state's regulation of the modern nuclear family by accommodating the piano among other things.

First instituted in the early 80s, the one-child policy was a government mandate that restricted heterosexual married couples in specific urban and rural areas to one child. The one-child policy was preempted by birth control policies of the 1970s, where Chinese officials signed off on birth-control goals that "[aimed] to reduce the annual rate of population growth" (Whyte, Feng, and Cai 2015, 149). The one-child policy was instituted in response to Chinese government officials' "search...to find any conceivable way to increase the per capita economic growth rate" (Ibid). According to such leaders, a "total fertility rate of...one [child] rather than two or higher would enable China to reach [the] long-run optimal population of [700 million or less]" (Ibid). The implementation of the policy targeted the female reproductive body through female 
sterilizations, IUD insertions, and, in some cases, forced abortions, where “'over-quota' pregnant women in...rural Guangdong...were ordered confined....while being subjected to harangues to get them to consent to abortions" (Ibid).

Aside from the forced abortions and various physiological reproductive controls enforced on women's bodies, the piano also operated as a significant social birth control mechanism that aided the implementation of the one-child policy. The piano served and continues to serve as a critical object of nuclear familial cohesion in the post-Revolution national project. As seen in my respondents' statements, their families of three struggled to accommodate the piano, for which they relocated, changed jobs, and separated. Their voices affirm Wu Zuqiang's claim: "when a child studies [the piano], his parents study too [so that] one makes three" (Melvin and Cai 2004, 312). The piano can thus be construed as the material glue for the Chinese nuclear family, where the placement of the piano in the home negotiated and regulated relations between Chinese parents and their only child. The significance of the piano to Chinese families is evidenced by the fact that the piano required hefty financial and emotional investments that could most practically be provided in families with one child. The daily practice routines, piano lessons, monetary investments, and time investments necessitated by piano study made it an ideal activity for families of three, where parents could effectively direct the bulk of their attention to the development of their child's piano playing capacities. In a sense, the piano embedded the social relations between parents and their (only) child - an instrument that facilitated understandings of the new nuclear family.

These social interests were supported by means of the piano's alignment with Confucian values. Chinese subjects hybridized their Confucian values with new understandings of Romantic ideals by adopting piano education. Confucian philosophy places deep importance on the effects of music training on a person's growth. Confucius marked music as the ideal form of training for the mind, where music "could be used to make the hearts of the people good" and represents "the best way of awakening the human spirit or human sentiments," where a person's character is improved by her exposure to music (Huang 2016, 168). 
Piano playing aligns particularly well with this Confucian notion given the technical demands of the instrument, the necessity of "disciplined practice and intense concentration" as well as the development of skills through "close contact with a private teacher" (Ibid 171). The Confucian link between one's character and one's engagement with music is manifested in the Chinese familial context, where music education emerged as a pragmatic familial tool integral to the development of the good, disciplined child.

However, gender pervades piano playing in the Chinese state in much deeper ways than simply disciplining proper boys and girls. As an instrument that implemented the one-child policy and disciplined the Chinese population, the piano was a device that regulated reproducing bodies and propagated a heteronormative project. The piano's significance as a crucial object of familial mediation in Chinese households opens up a sphere of politics in which Chinese women were more reluctant to have second children not only due to the one-child policy, but also due to the immense financial and temporal responsibilities of disciplining a second child pianist.

However, the piano's regulatory mechanism faces individual contestation. In the following section, I investigate the ways that Chinese women tacitly reimagine the familial implications of the piano in the American conservatory, exploring the "body-tool complex" in relation to the institution. The American conservatory regulates an individual relationship to the piano that displaces the familial basis in the Chinese state. Although the Chinese context leaves indelible traces on the ways Chinese women relate to the piano, their movement to the American conservatory invokes new relationships with the instrument.

\section{Romantic Influences in the American Music Conservatory}

When asked about their experiences as Chinese subjects in the western classical music world, my interviewees did not talk about Confucian ideals or their families. Instead, they described Romantic sentiment and loneliness. When I asked about the link between piano playing and disciplining proper femininities, Lidong Xu states: "piano playing shows 
one's love of music. It's not for anything. Also, 'proper' woman doesn't come from 'skills' like piano playing, it's a lady's understanding of human, life, and the world" (Lidong Xu, in conversation with the author, January 2017). Similarly, Anran Qian claims that "anyone can play the piano, it has nothing to do with gender" (Anran Qian, in conversation with the author, January 2017).

We can understand their responses as symptomatic of the educational structure of the American conservatory, which-unlike the Chinese familial context-necessitates a solitary relationship to the piano through its educational structures. The American music conservatory regulates Romantic notions through its curricular structure and practice regime. The ramifications of such educational structures are also felt in the form of loneliness unique to the experiences of Chinese women pianists in American conservatories.

\section{The Romantic Curricular Structure}

The American conservatory conditions a detachment between music and the social or political through its curriculum structure. Recall Hoffmann's notion of Romanticism that understands instrumental music as akin to a religion, where music delivers joy that is "nobler and more beautiful than anything experienced in this narrow world" that "comes to us from the unknown land" (Locke and Hoffmann 1917, 132). In the performance of instrumental music, Hoffmann's understanding calls for a depoliticized performance, in which the life of the performer or composer outside the performance is irrelevant to the communication of sublime music. American music conservatories reinforce these Romantic logics by conditioning an educational atmosphere of political and social disengagement. According to Mari Yoshihara, the conservatory disciplines against "active explorations of racial identity" where "discussions about history or current affairs are usually not part of conservatory student's educational experience" (Yoshihara 2007, 64). Students take classes in music history, but such courses "often lack analytical rigor and rarely nourish critical thinking about music's social or political functions or musicians' roles in society" (Ibid). Yoshihara interrogates this limited curriculum as a process of political and 
intellectual disengagement. For her, the American conservatory encourages an interpretation of music that disengages the performer's identity, demoting the extramusical as irrelevant and "secondary to the musician's artistic goal" (Ibid 198).

\section{The Lonely Practice Regime}

The conservatories' Romantic expectations are not only evident with the curricular structure, they are also evident in the structures of power that govern the practice regime. Extending from the Romantic notion of the solitary musician contacting the sublime through absolute music, the practice regime conditions solitary relationships to the piano. The constant need to practice has an unexpected effect. The practice regime engenders deep feelings of loneliness that extend from the demands of daily, regimented practice routines, where students must engage in "long periods of practicing or rehearsing, typically alone in a small practice studio" (Kingsbury 2010, 131). This systemic, routinized practice schedule conditions a solitary relationship to the piano that follows the logic of the "body-machine complex," where specific regulations for "contact between the body and the object" (the object being the piano) are disciplined by techniques of power (Foucault 1995, 152-153). Not only does practicing "[disciplines] the muscles of the hand in a highly specific function," but the discipline of practicing also serves as "a sensual kind of contemplation, a meditative muscle training" (Kingsbury $2010,132)$. The mind and the minute muscles of the hands are finetuned as a result of spending long periods of time alone. This "meditative muscle training" demands solitude, where effective practicing or "[contemplating]" necessitates individual work at the piano.

The ramifications of the solitary practice routine are manifested through the systemic feelings of loneliness among my respondents. Wu Liu highlights the particularity of Chinese women's experiences of loneliness. She states that: "Chinese international students are very lonely, I would say, more than others, they do work alone most of the time, and hang out with small [sic] group of people" (Wu Liu, in conversation with the author, January 2017). Jingci Liu stresses the impact of the practice regime on loneliness in the conservatory, where 
"learning [the piano] somehow means we have to get to used loneliness" (Jingci Liu, in conversation with the author, October 2016).

My respondents point to a particular loneliness in the American conservatory that differs from their experiences in China. I propose that the loneliness of practicing is made more salient in the conservatory setting given the discrepancies between their experiences in the Chinese familial context and the American conservatory. Chinese women have deep experiences of the Romantic Confucian outlook in China where the piano was socialized in the Chinese family. They came to a different Romantic outlook in the American conservatory, which disciplines a relationship to the piano premised on the idealization of the individual musician experiencing absolute music. Loneliness in the conservatory becomes more pervasive as a result of the necessity to "practice alone" in a "new/strange environment" (Liu, in conversation with the author, October 2016).

However, the American conservatory and Chinese family contexts are insufficient on their own in explicating the worlds of Chinese women pianists. These political spaces do not account for the complex ways that Chinese women generate sophisticated understandings of Romantic paradigms in joining two contexts together. In the following section, I examine the ways that Chinese women pianists refigure Romanticism when in American conservatories by subtle opposition to Romantic norms and the gendered, familial underpinnings of their relationships to the piano. By refiguring Romantic expectations to their own lives, Chinese women tacitly invert the regulations in the American conservatory and the Chinese family.

\section{Refiguring Romanticism}

When asked about their motivations for relocating to the United States to attend a conservatory, my interviewees frequently brought up the terms "life" and "freedom." Yuejiamin Ying points to the integral ways that the piano supports her life. She states:

For me, I love piano so much that I cannot imagine how my life would be like without the piano. It is already a part of me and my life. Be realistic 
[sic], I don't think I can make my living without piano, it is the only skill I have. (Yuejiamin Ying, in conversation with the author, October 2016)

Xueying Fan extends this notion of living through the piano, stating: "for now, piano is like a habit for me, I have been [living] with it for more than 10 years [sic]" (Xueying Fan, in conversation with the author, January 2017).

How is it that Chinese women pianists-despite the oppressive disciplinary frameworks that gird the transnational space of the conservatory and the use of the piano in the Chinese state-derive freedom and living strategies within Romantic paradigms? The sheer frequency with which my respondents describe their piano playing as fundamental to their lives affirms the significance of their particularity as Chinese women. These individuals make their social and political lives in the American conservatory relevant to ways of understanding Romantic frameworks in practice; their experiences of loneliness in the American conservatory and the cultural barriers they face in the United States are integrated into their own refashioning of Romantic norms.

The piano serves as a crucial tool for my respondents' identification as Chinese and American subjects. In her essay "Music as Technology of the Self," Tia DeNora claims: "music can be used as a device for the reflexive process of remembering/constructing who one is, a technology for spinning the apparently 'continuous' tale of who one 'is"' (DeNora 1999, 45). Although DeNora focuses on listeners' experiences of music as opposed to performers', she highlights the ways that music-making is intrinsically tied to the memories and identities of those who experience it. This is entwined with the complex ways that piano playing serves as a vital means for Chinese women to make sense of who they are in the midst of the challenges of being transnational subjects. Yuejiamin Ying takes an economic viewpoint by claiming that she needs the piano to "make [her] living." Ying states that piano playing is the only practical skill she has for the sake of maintaining financial stability. At the same time, she describes the piano as "a part of me and my life," in that her music is fused with her sense of self-knowledge, guiding her intuition on her life and her economic life-making strategies. Likewise, Sophia Zhou states: "[the piano] is important to me because it is what I do. And the 
more I do it, the more it speaks to me. It grows with my life and emotional experiences. It is like a home base for my thoughts and my abilities" (Zhou, in conversation with the author, 2017). Zhou describes her connection to music as a tool of self-construction that "grows with [her] life and emotional experiences." Interestingly, Zhou does not claim that she "grows" alone in her pianistic abilities through life-rather, she and her music-making grow together, where the piano takes on new meanings as she encounters new affective circumstances. Zhou's extramusical experiences are thus inherently tied to her life as a musician. The fusing of their lives with music takes after the notion of the Romantic life-a life of sublimity through music where music is a device for achieving a higher purpose. They follow the Romantic logic of the solitary musician brought forth by the American conservatory as well as the Chinese familial logic of the child's betterment through Romantic music-making.

Chinese women invert what was once an imposition upon them into a creative force. Where Romanticism was once a means of foreclosure and discipline in both the Chinese and American contexts, Chinese women, by living in alignment with Romantic ideals, invert these so-called oppressive forces into productive devices for expression. Recall Cusick's notion of the faithful performance that demands the disappearance of the extramusical self. This necessary disappearance is untenable-the political and social ways that the relationship to the piano is understood are too important, too entwined with the ways that these women understand themselves for them to disappear in accordance to Romantic paradigms. Chinese women fuse their understandings of themselves with the piano as a strategy of surviving the loneliness of the American conservatory and their memories of their families' accommodations of their piano study. The piano is inseparable from two vastly different territories and contexts-first, the memories of growing up in the intimate sphere of the Chinese family during the era of the one-child policy, and secondly, the feelings of loneliness in the American conservatory as a result of the isolation of the institutionalized practice regime. 
The nuanced ways that Chinese women rework Romantic ideals are not simply manifested in my respondents' statements about the meanings of the piano in their lives; rather, these destabilizations are manifested in the bodied ways that my respondents make music. My respondent Sophia Zhou offers a personal experience of playing the piano where the act of performance demands intervention by extramusical factors:

For instance, the beginning of Schumann's Kreisleriana is a whirlwind of frenziness and unruliness, and that's something the performer has to feel within himself. But it's impossible to execute the passages well if you actually experience all that in your body...I really try to stay at the back of my stomach, as if that's the home base for the emotions embodied in music, and stay controlled at the front of my body. You feel a little split but it's an amazing place to be. (Sophia Zhou, in conversation with the author, January 2017)

Zhou's statement undeniably extends from Romantic paradigms. Her description of the necessity of splitting her body so that she "[stays] at the back of [her] stomach" and conceals emotional engagement from the "front of [her] body" is a unique, bodied refiguration of Suzanne Cusick's notion of the "spectacle of the disappearing Self." Similarly, she affirms Cusick's notion of the performing the "persona" in accordance with the composer's ideals, where the performer must feel the "frenziness and unruliness" in Schumann's Kreisleriana.

Although Zhou's demand to enter "feelings" of "frenziness" and "unruliness" rehabilitate Romantic norms of the ideal performance, these "feelings" are intrinsically tied to her political and social memories of a life in the Chinese familial context and her current life in the American conservatory. By complying with the very Romantic expectations that discipline the Chinese familial context and the American conservatory, Zhou tacitly inverts regulatory norms. Since her piano playing carries the memories of two different Romantic traditions, when she plays Kreisleriana true to Schumann's ideals, she does so in a way where her political and social self is inseparable from the performance. When she feels "frenziness and unruliness," she draws from the very same self that accommodates the social challenges of the American conservatory, 
making her experiences as a Chinese subject relevant to her performance of Kreisleriana.

My respondents' refigurations of Romantic norms can be interpreted through José Esteban Muñoz's notion of the "disidentificatory subject." In Muñoz's Disidentifications, the author theorizes a generative "modality of performance...as disidentification” (Muñoz 1999, ix). Though Muñoz attends to the experiences of queer bodies, his notion of disidentification is grounded in the act of performance and can be attributed to the ways that Chinese pianists like Zhou refigure regulations through performing. Muñoz's theory affirms the tacit potentials of inversion within the act of performance. He draws on Judith Butler's claim of the potentials within the failure of identification, where nonconforming bodies invert their own misrecognition into a means of personal expression. Butler claims that the "'possibilities of politicizing [the] experience of misrecognition, this uneasy sense of standing under a sign to which one does and does not belong"' lies in "'the affirmation of that slippage, that the failure of identification, [as] itself the point of departure for a more democratizing affirmation of internal difference'" (Ibid 12). Butler refers to queer identities in heteronormative structures; Muñoz adapts this to the study of queer performances. Though my respondents are not queer bodies in heteronormative structures, these experiences of misrecognition are relevant to the nuanced strategies of Chinese women pianists. Romantic norms that condition the disappearance of the self from the performance can be understood as structures that condition misrecognition. These norms do not attend to Chinese women's unique transnational experiences. When Chinese women perform in accordance to expectations of disappearing the self, they refigure Romantic logics to their particularity in accordance with Muñoz's logic of the disidentificatory subject. By performing in alignment with the very means of their misrecognition, Chinese women attend to their own particularity. This act of inversion through performance generates worlds in which Chinese women refigure norms by affirming the slippages within them.

\section{Conclusion}


The relationship between Chinese women and Romantic logics indicates the need for a nuanced understanding of Romanticism's presence in performances - one that does not necessarily overturn Romanticism but rather works within the paradigm. When classical music reviewer Nordlinger characterized Wang's garment as "stripper-wear" and Swed spoke of how the "Bowl might have been forced to restrict admission to any music lover under eighteen not accompanied by an adult," both critics fail to understand what Wang is generating through her performance. They are oblivious to how their own fantasy of performance complies with the Romantic paradigms that have shaped Wang's experiences as a piano student in China and in the American conservatory. Critics assume the disappearance of the performer's extramusical self to the extent that they fail to see the ways that Chinese women pianists make their particularity central to their performances. For Wang and others, performance is not an act of submission, but a means of self-constitution. Critics' misrecognition of the constitutive potentials within performances highlights the importance of feminist critique to performance inquiry. Feminism demands the recognition Wang's experiences in the Chinese state and the American conservatory. Wang's performance is not just a feminist endeavor due to her identity as a Chinese woman, but also because of her vulnerability to larger paradigms and disciplinary structures. The ways Chinese women refigure piano playing to their particularity leaves us at a dynamic crossroads between feminism and performance inquiry, raising the question: how can we refigure listening so as to acknowledge their lives in political spaces and not demand their disappearance?

\section{References}

Ameer, Amanda. "Does Your Mother Know That You're Out?" Life's A Pitch. N.p., 8 Aug. 2011. Web. 30 Sept. 2016.

Cao, Ting. "The Impacts of Modernity on Family Structure and Function : A Study among Beijing, Hong Kong and Yunnan Families." Theses \& Dissertations (2012): n. pag. Web. 
Chou, Oliver K., (Author). "Maestro Li Delun and Western classical music in the People's Republic of China: A Personal Account." ACMR reports: Journal of the Association for Chinese Music Research 1 Jan. 1999: 23-46. Print.

Cusick, Suzanne. "Gender and the Cultural Work of a Classical Music Performance."

Repercussions 3 (1994): 77-110. Web. 30 Sept. 2016.

Daverio, John. Nineteenth-Century Music and the German Romantic Ideology. Schirmer Books, 1993. Print.

DeNora, Tia. "Music as a technology of the self." Poetics 27 (1999): 31-56. Web. 22 Jan. 2017.

Espiritu, Yen Le. Body Counts : The Vietnam War and Militarized Refuge(es). Oakland, California: University of California Press, 2014. Print.

Foucault, Michel. Discipline and Punish. New York: Random House, 1995. Print.

Griffiths, Noola K. "The fabric of performance: values and social practices of classical music

expressed through concert dress choice." Music Performance

Research (2011): 30-48. mpr-online.net. Web. 22 Jan. 2017.

Huang, Hao. "Why Chinese People Play Western Classical Music:

Transcultural Roots of Music Philosophy." International Journal of Music Education (2011): 0255761411420955. ijm.sagepub.com. Web. 22 Sept. 2016.

Kingsbury, Henry. Music Talent \& Performance: Conservatory Cultural System. Temple University Press, 2010. Print.

Kraus, Richard Curt. Pianos and Politics in China: Middle-Class Ambitions and the Struggle over Western Music. New York: Oxford University Press, 1989. Print.

Lerner, Murray. From Mao to Mozart [videorecording] : Isaac Stern in China. New York: distributed by New Video, 2008. Film. 
Locke, Arthur Ware, and E. T. A. Hoffmann. "Beethoven's Instrumental Music: Translated from E. T. A. Hoffmann's 'Kreisleriana' with an Introductory Note." The Musical Quarterly 3.1 (1917): 123-133. Print. Malcolm, Janet. "Yuja Wang and the Art of Performance." The New Yorker. 5 Sept. 2016. Web. 14 Dec. 2016.

Muñoz, Jose Esteban. Disidentifications: Queers of Color and the Performance of Politics. University of Minnesota Press, 1999. Print.

Melvin, Sheila, and Jindong Cai. Rhapsody in Red: How Western Classical Music Became Chinese. Algora Publishing, 2004. Print.

Nordlinger, Jay. "Once More, with Feeling: Yuja Does Carnegie." N.p., n.d. Web. 29 Sept. 2016.

Rose, Terez. "Pianist Yuja Wang's Very Short Dresses and Very Big Talent." The Classical Girl. 31 May 2014. Web. 30 Sept. 2016.

Swed, Mark. "Music Review: Yuja Wang and Lionel Bringuier at Hollywood Bowl." LA Times Blogs - Culture Monster. 3 Aug. 2011. Web. 29 Sept. 2016.

Tadiar, Neferti. "Life-Times of Becoming Human." ARCADE. N.p., n.d. Web. 3 Dec. 2016.

Whyte, Martin King, Wang Feng, and Yong Cai. "Challenging Myths About China's One-Child Policy." The China Journal 74 (2015): 144-159, 244245. Print.

Yoshihara, Mari. Musicians from a Different Shore [electronic Resource] : Asians and Asian Americans in Classical Music. Philadelphia: Temple University Press, 2007. Print. 